\title{
Indirect Spectrophotometric Method for the Determination of Mefenamic Acid in Pharmaceutical Formulations*
}

\author{
Nief R. Ahmed \\ Zainab M. Al-mufty \\ The State Company for Drug Industries and Medical Appliances \\ Mosul , Iraq
}

(Received 10/11/2008 ; Accepted 4/5/2009)

\begin{abstract}
A simple, sensitive and accurate spectrophotometric method for the determination of mefenamic acid in pure form and in some pharmaceutical formulations was developed. The method is based on the oxidation of mefenamic acid by iron(III), and subsequent complexation of iron(II) with o-phenanthroline, forming a red-colored complex (ferroin) having the maximum absorbance at $510 \mathrm{~nm}$. Beer's law is obeyed in the concentration range of 0.4-2.0 $\mu \mathrm{g} \backslash \mathrm{ml}$, the molar absorptivity and Sandell's sensitivity are $2.9 \times 10^{4} \mathrm{~L} . \mathrm{mol}^{-1} . \mathrm{cm}^{-1}$ and $8.3 \mathrm{ng} . \mathrm{cm}^{-2}$, respectively and the relative standard deviation (RSD) is less than 2.0 $(\mathrm{n}=10)$. The limits of detection and quantitation are 0.065 and $0.195 \mu \mathrm{g} \cdot \mathrm{ml}^{-1}$,respectively. The method is applied successfully to determination of mefenamic acid in some pharmaceutical formulations (capsules and tablets). The common excipients do not interfere with the proposed method. A statistical comparison of these results with those of official method using ( $t$ and $F$ ) values at 95\% confidence level shows good agreement and indicates no significant difference in the precision and the present method has good validity.
\end{abstract}

Keyword: Mefenamic acid, Spectrophotometry; Iron (ш); phenanthroline

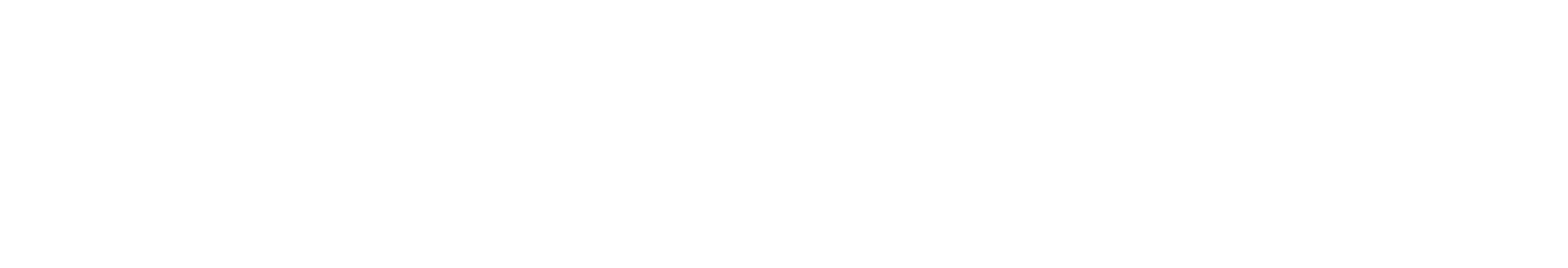

مُ وصفطريقةطية بسيطة ومشلسة وذات رقة عالية لقدير حلمض الميفينمك في حالته القية وفي

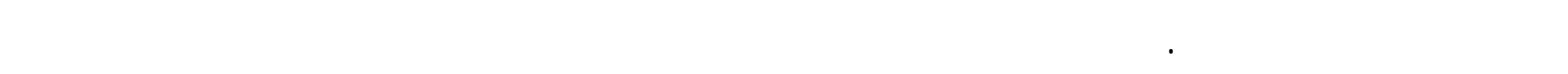
القايل الحديد الثنائي والذي بدوره يكون معقد لحمر اللون مع كلثف اورثو فينائنرولين (الفروين) والذي له له

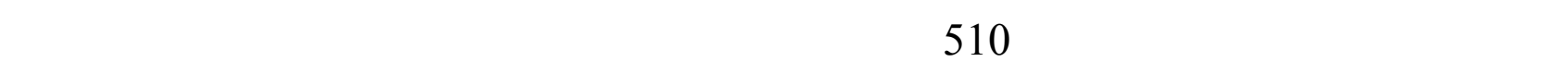

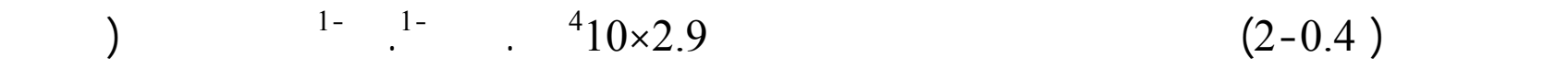

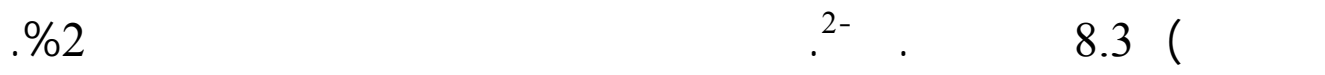

*م إقاه في المؤتمر العلمي الأول للكيمياء المنعد بتاريخ 22-23 نيسان 2008 فى قم الكيمياء /كلية العلوم/جلمعة الموصل 
وان حد الكثف والحد الكمي كانا 0.065 و0.195 مايكرو غرلم.مل -1 على التوالي. وطقت الطريقة بنجاح

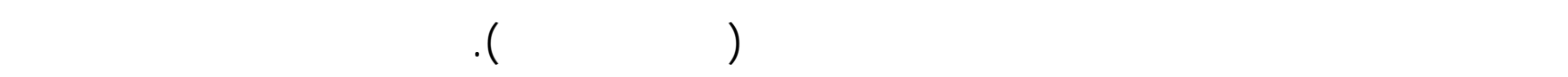

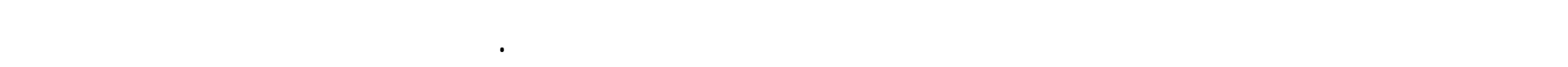

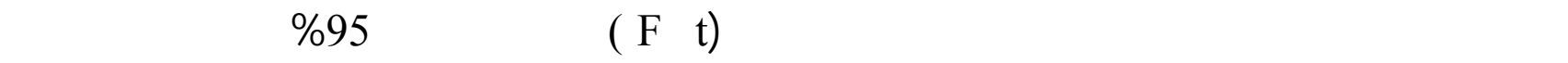
صلاحية الظبق التحليلي الطاريقة.

\section{INTRODUCTION}

Mefenamic acid: N-2, 3-xylylanthranilic acid, is an analgesic, antipyretic with minor anti-inflammatory properties (The pharmaceutical codex, 1979).<smiles>Cc1cccc(Nc2ccccc2C(=O)O)c1C</smiles>

(Mefenamic acid)

(N-2, 3-xylylanthranilic acid)

Mefenamic acid is used in musculoskeletal and joint disorder such as rheumatoid arthritis, osteoarthritis (Martindale, 1999) and primary dysmenorrheal (Zhang and Li, 1998 and Remington,1995). Different methods for the determination of mefenamic acid have been described, such as titrimetry (official method) for the assay of pure form and pharmaceutical preparation using sodium hydroxide as titrant and phenol red as indicator (British pharmacopeia, 2005), HPLC (Chao et al., 1997 and Hirai et al., 2002) gas chromatography (Chao, 1997) and cloud point extraction with spectrofluorimetry and spectrophotometry. (Tabrizi, 2006).

The most widely used methods for the determination of mefenamic acid are spectrophotometric methods (Idown et al., 2002; Sastry and Rao,1989; Sastry and Rao, 1987, Dinc et al., 2002; Gangwal et al.,1996; Sastry and Rao,1989; Aman et al., 2005, Zommer et al.,1986 and Alarfaj et al., 2009). However, all of these methods suffer from one or more disadvantage such as insufficient sensitivity, selectivity, tedious and use of complex solvent extraction procedures. Therefore, a simple method for assay of mefenamic acid is necessary for routine analysis and quality evaluation.

\section{Apparatus}

\section{EXPERIMENTAL}

Spectro-scan $50 \mathrm{UV}$ - visible (double beam) spectrophotometer with $1.0 \mathrm{~cm}$ quartz cells was used for absorption measurements, and Jenway $3310 \mathrm{pH}$ meter was used for $\mathrm{pH}$ measurements. 


\section{Reagents}

All chemicals used were of analytical or pharmaceutical grade and distilled water was used throughout.

\section{Mefenamic acid stock solution:( 100 ppm).}

This solution was prepared by dissolving $0.01 \mathrm{~g}$ of mefenamic acid in $100 \mathrm{ml} 0.01 \mathrm{~N}$ $\mathrm{NaOH}$ solution.

\section{Mefenamic acid standard solution $(10 \mathrm{ppm})\left(4.1 \times 10^{-5} \mathrm{M}\right)$}

This solution was prepared by diluting $10 \mathrm{ml}$ of stock solution to $100 \mathrm{ml}$ with distilled water in a volumetric flask.

\section{Ferric chloride solution $0.1 \%$ in $0.01 \mathrm{~N}$ HCl}

This solution was prepared by dissolving $0.1 \mathrm{~g}$ of ferric chloride in $100 \mathrm{ml}$ of distilled water containing $2 \mathrm{ml}$ of concentrated $\mathrm{HCl}$

\section{Buffer solution(pH 3)}

This solution is prepared by mixing $16.2 \mathrm{ml}$ of $0.1 \mathrm{M}$ chloroacetic acid with $8.8 \mathrm{ml}$ of $0.1 \mathrm{M} \mathrm{KOH}$, then the volume is completed to $100 \mathrm{ml}$ with distilled water in a volumetric flask (Zommer and Bojarowicz,1986).

\section{1,10-phenanthroline solution: $1 \%$ in $0.01 \mathrm{~N} \mathrm{HCl}$}

This solution was prepared by dissolving $1 \mathrm{~g}$ of 1,10 phenanthroline in $100 \mathrm{ml} 0.01 \mathrm{~N}$ $\mathrm{HCl}$ solution.

\section{Recommended procedure}

A known volume of sample solution containing 10-50 $\mu \mathrm{g}$ of mefenamic acid was transferred into a $25-\mathrm{ml}$ calibrated flask followed by $3 \mathrm{ml}$ of ferric chloride solution then 2 $\mathrm{ml}$ of 1,10-phenanthroline solution and $2 \mathrm{ml}$ of buffer solution $\mathrm{pH} 3.0$ were added, diluting the solution to the mark with distilled water, the flask was placed in a water bath maintained at $70 \pm 3{ }^{\circ} \mathrm{C}$ for $15 \mathrm{~min}$. The absorbance of the red-colored product was measured at $510 \mathrm{~nm}$ against a reagent blank.

\section{Analysis of pharmaceutical preparations}

\section{Tablets}

Weigh and powder 10 tablets. Dissolve a quantity of the powdered tablets containing 0.01 $\mathrm{g}$ of mefenamic acid in about $100 \mathrm{ml}$ of $0.01 \mathrm{~N}$ sodium hydroxide. It was shaken thoroughly for about 10-15 min, and filtered. The filtrate was made up to $1 \mathrm{~L}$ with distilled water. Treate $3 \mathrm{ml}$ of this solution as mentioned under recommended procedure.

\section{Capsules}

Dissolve a quantity of the mixed contents of 10 capsules containing $0.01 \mathrm{~g}$ of mefenamic acid in $100 \mathrm{ml}$ of $0.01 \mathrm{~N}$ sodium hydroxide and mixed for 10-15 mint and then filtered. The filtrate was made up to $1 \mathrm{~L}$ with distilled water. Treate $3 \mathrm{ml}$ of this solution as described under recommended procedure. 


\section{RESULTS AND DISCUSSION}

The method is based on the oxidation of mefenamic acid by iron (III) in the presence of o-phenanthroline in acidic medium. The iron (II) formed was quantitively and rapidly converted to the stable tris (o-phenanthroline) iron (II) complex (ferroin) having an absorption maximum at $510 \mathrm{~nm}$ (Marczenko, 1976)as shown below (Fig. 1) thus permitting the indirect estimation of mefenamic acid. The reaction variables were optimized by varying each variable while keeping others constant for obtaining maximum absorbance.<smiles>CCCCCC(C)C</smiles>
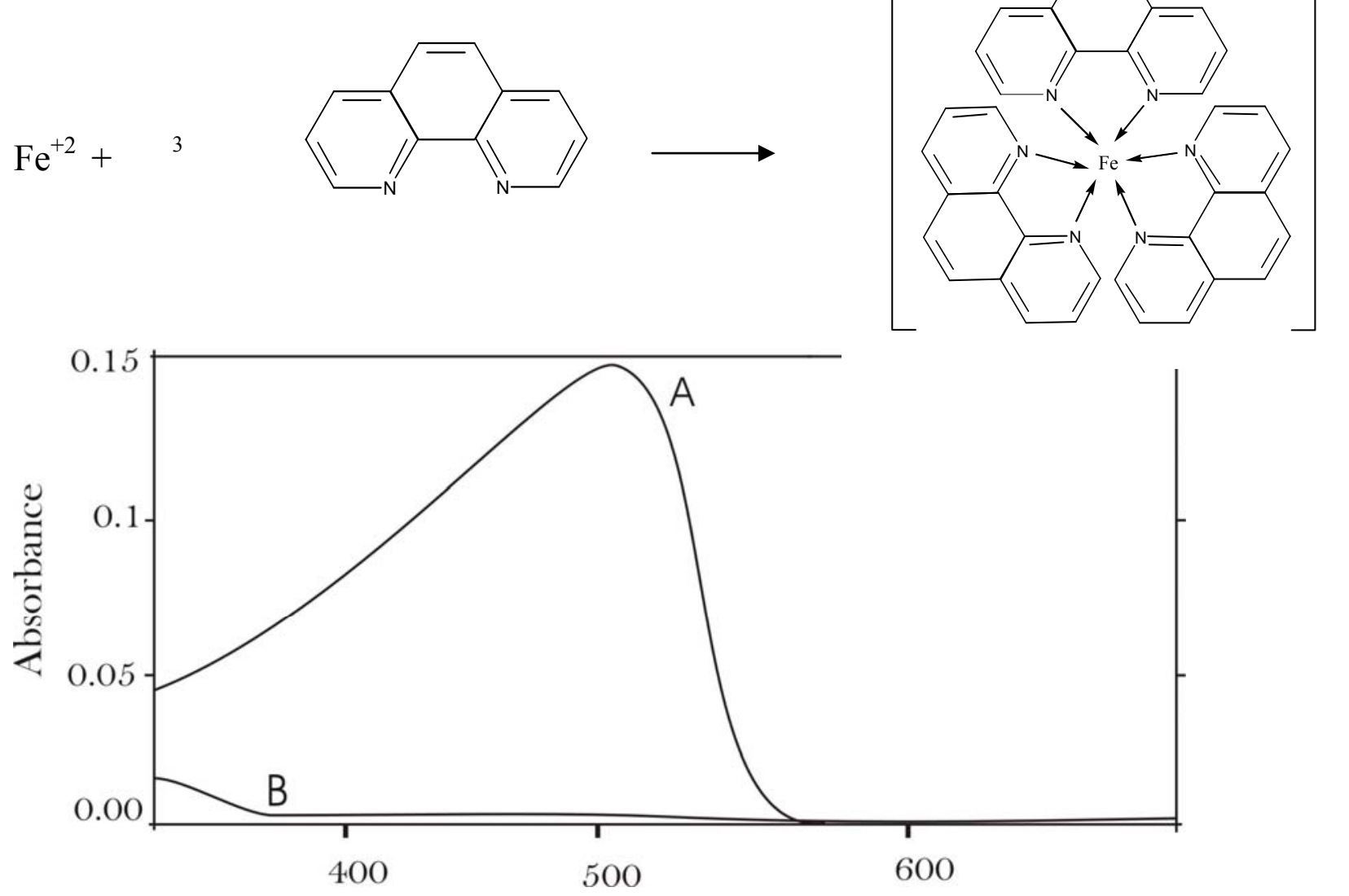

$\lambda \mathrm{nm}$

Fig 1: Absorption spectra of A :30 $\mu \mathrm{g} / 25 \mathrm{ml}$ of mefenamic acid with $\mathrm{FeCl}_{3^{-}}$ phenanthroline against reagent blank. B:blank against distilled water. 
The oxidation reaction was found to be quantitative in acidic medium, the $\mathrm{pH}$ 2.0-4.0 is considered optimum. Then, a $\mathrm{pH}$ of 3.0 is selected for the subsequent investigation. Four types of buffer solution $\mathrm{pH} 3$ of different compositions (Perrin and Dempsey, 1974) have been tested for this purpose. Table (1) shows the results of this investigation.

Table 1: Effect of different buffers on the absorbance

\begin{tabular}{|c|c|c|c|c|}
\hline \multirow{2}{*}{$\begin{array}{l}\text { Ml of buffer } \\
\text { solution }\end{array}$} & \multicolumn{4}{|c|}{ Absorbance } \\
\hline & B1 & B2 & B3 & B4 \\
\hline 0.5 & 0.142 & 0.097 & 0.062 & 0.095 \\
\hline 1 & 0.147 & 0.116 & 0.081 & 0.099 \\
\hline 2 & 0.147 & 0.116 & 0.093 & 0.108 \\
\hline 3 & 0.147 & 0.115 & 0.095 & 0.108 \\
\hline 4 & 0.145 & 0.109 & 0.096 & 0.112 \\
\hline 5 & 0.142 & 0.110 & 0.095 & 0.108 \\
\hline
\end{tabular}

B1: Buffer of $0.1 \mathrm{M}$ chloroacetic acid- $0.1 \mathrm{M} \mathrm{KOH}$

B2: Buffer of $0.1 \mathrm{M}$ glycine $-0.2 \mathrm{M} \mathrm{HCl}$

B3: Buffer of 0.2M KCL-0.2M HCl

B4: Buffer of $0.1 \mathrm{M}$ citric acid- $0.2 \mathrm{M} \mathrm{Na}_{2} \mathrm{HPO}_{4}$

It was found that $1-3 \mathrm{ml}$ of buffer $\mathrm{B} 1$ gives high sensitivity and $2.0 \mathrm{ml}$ has been used for subsequent experiments.

The effect of the amount of $\mathrm{FeCl}_{3}$ and o-phenanthroline amounts on the absorbance was investigated. A maximum and constant absorbance was found with $3.0 \mathrm{ml} \mathrm{FeCl}$ and $2.0 \mathrm{ml}$ of $1 \% \mathrm{o}$-phenanthroline, which were therefore adopted as being optimal.

The color reaction occurred even at room temperature $\left(25^{\circ} \mathrm{C}\right)$, though at higher temperature the color developed more rapidly. The maximum absorbance was observed after $15 \mathrm{~min}$ of heating at $70^{\circ} \mathrm{C}$. A temperature of $70^{\circ} \mathrm{C}$ and a reaction time of 15 min were selected for reproducible results.

Under the experimental conditions described, Beer's law is obeyed over the concentration range $0.4-2.0 \mu \mathrm{g} / \mathrm{ml} \mathrm{Fig[2].} \mathrm{Linear} \mathrm{regression} \mathrm{equation:} \mathrm{A}=0.0021+0.048 \mathrm{C}(\mathrm{r}=0.9993 \mathrm{n}=$ 8).

Where $\mathrm{A}$ is the absorbance and $\mathrm{C}$ is the concentration in $\mu \mathrm{g} \backslash \mathrm{ml}$

The apparent molar absorptivity was $2.9 \times 10^{4} \mathrm{~L} \cdot \mathrm{mol}^{-1} . \mathrm{cm}^{-1}$ and Sandell's sensitivity was 8.3 ng. $\mathrm{cm}^{-2}$. The limit of detection and quantification were evaluated as (Bassavaiah and Somashekar, 2007):

$$
L O D=3.3 \frac{\text { So }}{b} \quad \text { LOQ }=3 \mathrm{LOD}
$$

Where $\mathrm{b}$ is the slope and So is the standard deviation of the regression line. The limit of detection was $0.065 \mu \mathrm{g} . \mathrm{ml}^{-1}$ and the limit of quantification as the lowest standard 
concentration which could be determined with acceptable accuracy, and precision was 0.195 $\mu \mathrm{g} . \mathrm{ml}^{-1}$

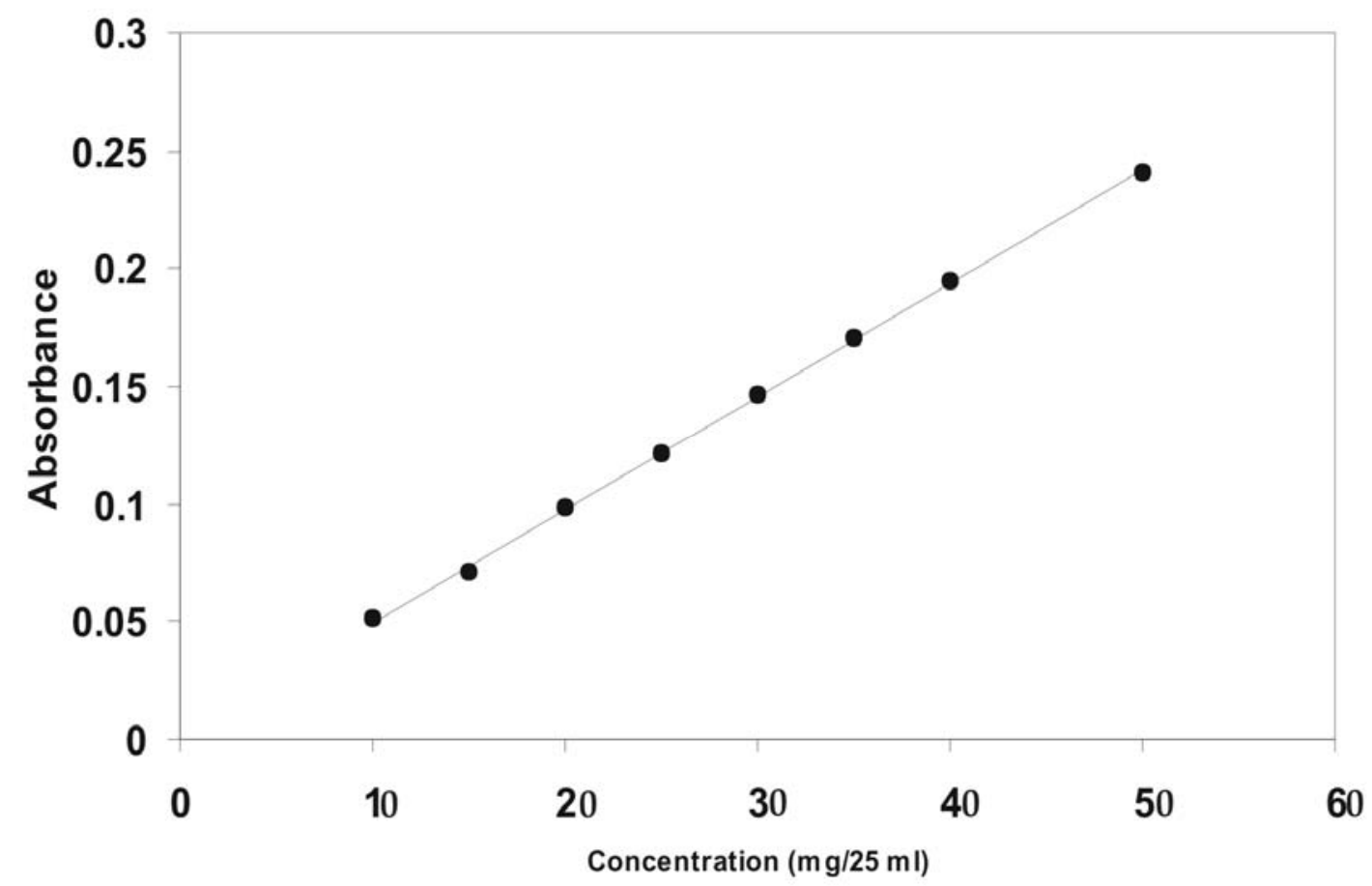

Fig 2: Calibration graph of mefenamic acid

\section{ccuracy and precision}

The accuracy and precision of the method were established by analyzing the pure drug solution at three different levels. The average recovery which is a measure of accuracy is $100 \pm 0.92 \%$ revealing high accuracy of the method. The relative standard deviation (RSD), which is an indicator of precision, is better than $\pm 2.0 \%$ the results are complied in Table(2).

Table 2: Optical characteristics and statistical data for regression equation of the proposed method

\begin{tabular}{|l|c|}
\hline Parameters & Value \\
\hline$\lambda \max (\mathrm{nm})$ & 510 \\
\hline $\mathrm{pH}$ & 3.0 \\
\hline Beer's law limits, $\left(\mu \mathrm{g} \cdot \mathrm{ml}^{-1}\right)$ & $0.4-2.0$ \\
\hline Molar absorptivity, $\left(1 . \mathrm{mol}^{-1} . \mathrm{cm}^{-1}\right)$ & $2.9 \times 10^{4}$ \\
\hline Limit of detection, $(\mu \mathrm{g} \backslash \mathrm{ml})$ & 0.065 \\
\hline Limit of quantification, $(\mu \mathrm{g} \backslash \mathrm{ml})$ & 0.195 \\
\hline Sandell's sensitivity, $\left(\mathrm{ng} \backslash \mathrm{cm}^{2}\right)$ & 8.3 \\
\hline Correlation coefficient $(\mathrm{r})$ & 0.9993 \\
\hline Regression equation $(\mathrm{A}=\gamma+\mathrm{bx})$ & $\mathrm{A}=0.0021+0.048 \mathrm{C}$ \\
\hline Intercept $(\gamma)$ & 0.0021 \\
\hline Slope $(\mathrm{b})$ & 0.048 \\
\hline Recovery, $(\%)$ & $100 \pm 0.92$ \\
\hline Relative standard deviation, $(\%)$ & $<2.0$ \\
\hline
\end{tabular}


INTERFERENCES

To study the potential interference from the commonly used excipients and other additives such as povidone, starch, talc, microcrystalline cellulose, magnesium stearate and mannitol, recovery studies were carried out. Under the experimental conditions employed, to a known amount of drug $(30 \mu \mathrm{g} \backslash 25 \mathrm{ml})$, excipients in different concentrations were added and analyzed. Results of the recovery analysis are presented in Table (3). Excipients at the concentration shown in Table (3) don't interfere with the assay. In addition, recoveries in most cases were around $100 \%$.

Table 3: Determination of mefenamic acid in presence of excipients

\begin{tabular}{|c|c|c|}
\hline Excipients & $\begin{array}{c}\text { Amount taken } \\
(\boldsymbol{\mu g} \backslash \mathbf{m l})\end{array}$ & Average recovery $\boldsymbol{*}^{\mathbf{~}}$ \\
\hline Talc & 300 & 99.5 \\
& 1000 & 100.05 \\
\hline Mannitol & 300 & 100.08 \\
& 1000 & 99.91 \\
\hline Mg-stearate & 300 & 100.05 \\
& 1000 & 99.93 \\
\hline Povidine (polyvinyl & 300 & 100.0 \\
pyrrolidone) & 1000 & 99.96 \\
\hline Starch & 300 & 100.08 \\
& 1000 & 100.05 \\
\hline Microcrystalline cellulose & 300 & 99.83 \\
& 1000 & 99.94 \\
\hline
\end{tabular}

* Average of 6 replicate analyses

\section{APPLICATION OF THE PROPOSED METHOD}

The proposed method was successfully applied to the analysis of mefenamic acid in capsules and tablets. The results of analysis for pharmaceutical formulations Table (4) were compared statistically by student t-test and by the variance ratio F-test with those obtained by official method at 95\% confidence level. The calculated $t$-and $F$ - values did not exceed the theoretical values indicating that there was no significant difference between the precision of the proposed and official methods. 
Table 4: Assay of mefenamic acid in pharmaceutical formulations.

\begin{tabular}{|l|l|l|l|l|}
\hline $\begin{array}{l}\text { Pharmaceutical } \\
\text { formulations supplied by } \\
\text { NDI }\end{array}$ & \multicolumn{2}{|l|}{ Amount of mefenamic acid* } & $\begin{array}{l}\text { t } \\
\text { Value }\end{array}$ & $\begin{array}{l}\text { F } \\
\text { Value }\end{array}$ \\
\hline $\begin{array}{l}\text { Ponstadin capsules } \\
\text { (250 mg/capsule) }\end{array}$ & 250.83 & 249.23 & 1.52 & 1.31 \\
\hline $\begin{array}{l}\text { Ponstadin tablets } \\
\text { (500 mg/tablets) }\end{array}$ & 501.01 & 498.83 & 1.99 & 1.18 \\
\hline
\end{tabular}

* Mean of ten determinations.

$\mathrm{T}$ values $(\mathrm{n}=10$, at $95 \%$ confidence level tabulated value 2.262$)$

$F$ values $\left(n_{1}\right.$ and $n_{2}=10$, at $95 \%$ confidence level tabulated value 3.18 )

\section{CONCLUSION}

The spectrophotometric method proposed is simple, sensitive, rapid, low-cost, does not involve solvent extraction steps and gives precise and accurate results. The proposed method was successfully applied to analysis of mefenamic acid in tablets and capsules.

\section{REFERENCES}

Alafraj, N. A.; Altamimi, S. A. ; Almarshady, L. Z. (2009). Spectrophotometric determination of mefenamic acid in pharmaceutical preparations, Asian J. Chem., 21, 217-226.

Aman, T.; Kazi, A. ; Mateen, B.( 2005). p- (dimethylamino) benzaldelyde as a new chromogenic reagent for the determination of nonsteroidal anti-inflammatory drug by first-order derivative spectrophotometery. Anal. Lett., 38,1899-1912.

Bassavaiah, K. ; Somashekar, B.C.( 2007). Quantitation of rantidine in pharmaceuticals by titrimetry and spectrophotometry using dichromate as the oxidimetric reagent. $J$. Iranian Chem. Soc., 4, 78-88

British Pharmacopeia(.2005). 1001p.

Chao, T.C.; Yao.Ong., Y. S. E ; Koh, T. ( 1997). Acid and neutral drug screen in blood with quantitation using microbore high performance liquid chromatography- diod array detection and capillary gas chromatography-flame ionization detection. For. Sci. Intern., 90, 205-214.

Dinc-E; Yucesoy, C. ; Onnr, F.( 2002). Simultaneous spectrophotometric determination of mefenamic acid and paracetamol in pharmaceutical preparation using ratio spectra derivative spectrophotometric and chemometric methods. J. Pharm. and Biomed. Anal., 28,1091-1100.

Gangwal, S. ; Sharma, A. (1996). Simultaneous spectrophotometric determination of mefenamic acid and paracetamol in combined pharmaceutical dosage forms. Indian J.. Pharm. Sci. 58, 216-218.

Hirai, T.; Metsumoto, S. ; Kishi, I.( 1997). Simultaneos analysis of several non-steroidal anti-inflammatory drugs in human urine by hplc with normal solid-phase extraction. J. Chromatogr. B, ,692, 375-388. 
Idown, S.; Tambo, S.; Adegoke, A. ; Olaniyi, A.( 2002). Novel colorimetric assay of mefenamic acid using 4-amino-3,5-dinitrobenzoic acid. Trop. J. Pharm. Res., 1, 1522.

Marczenko, Z. (1976). Spectrophotometric Determination of Elements. Ellis worwood limited, Chicheaster, 309-312.

Martindale, (1999)." The Complete Drug Reference". The Pharmaceutical Press, London, $51 \mathrm{p}$.

Perrin, D. D. ; Dempsey, B.(1974). "Buffer for pH and Metal Ion Control". Champan and Hall Ltd, London. pp. 132-136.

Remington, (1995). "The Science and Practice of Pharmacy", Mack Publishing Company. Easton Peunsylvania, Vol. 2, 1215 p.

Sastry, C. ; Rao, A., (1995). Spectrophotometric method for the determination of pentazocine and mefenamic acid. Indian J. .Pharm. Sci., 1987, 49, 95-96.

Sastry, P., Prasad, R. ; Suryanarayana, V. ( 1989). Extractive spectrophotometric determination of some anti-inflammatory agents with methylene blue. Analyst, 114, 513-515.

Sastry, S.P. ; Rao, A. R. (1989). Spectrophtometric determination of some analgesic and anti-inflammatory agents with 3-methyl-2-benzothiazone hydrazone hydrochloride. Microchim. Acta , 97, 237-244.

Tabrizi, A. B.(2006). Determination of mefenamic acid in human urin by means of two spectroscopic methods by using cloud point extraction methodology as a tool for treatment of samples. Bull Korean Chem. soc. 27, 1780-1784.

"The Pharmaceutical Codex", London, (1979). 520 p.

Zhang, W.Y. ; Wan, L.1, (1998). Efficacy of minor analgesics in primary dysmenorrhea. asystematic review. Brit. J. Obst. and Gynaec., 105,780-789.

Zommer, S. ; Bojarowicz, H. (1986). Spectrophotometric investigations on protolytic equilibria of mefenamic acid and determinations by means of fe (iii) in methanolaqueous media. J. Pharm. Biomed. Anal., 4, 475-481. 